University of Nebraska - Lincoln

DigitalCommons@University of Nebraska - Lincoln

Papers in the Earth and Atmospheric Sciences

Earth and Atmospheric Sciences, Department

7-1936

\title{
A PLEISTOCENE LAKE IN THE WHITE RIVER VALLEY
}

\author{
Paul MacClintock \\ Princeton University \\ Erwin Hinckley Barbour \\ University of Nebraska-Lincoln \\ C. B. Schultz \\ Nebraska State Museum \\ Alvin Leonard Lugn \\ University of Nebraska-Lincoln
}

Follow this and additional works at: https://digitalcommons.unl.edu/geosciencefacpub

Part of the Earth Sciences Commons

MacClintock, Paul; Barbour, Erwin Hinckley; Schultz, C. B.; and Lugn, Alvin Leonard, "A PLEISTOCENE LAKE IN THE WHITE RIVER VALLEY" (1936). Papers in the Earth and Atmospheric Sciences. 359.

https://digitalcommons.unl.edu/geosciencefacpub/359

This Article is brought to you for free and open access by the Earth and Atmospheric Sciences, Department of at DigitalCommons@University of Nebraska - Lincoln. It has been accepted for inclusion in Papers in the Earth and Atmospheric Sciences by an authorized administrator of DigitalCommons@University of Nebraska - Lincoln. 


\title{
A PLEISTOCENE LAKE IN THE WHITE RIVER VALLEY
}

\author{
PAUL MACCLINTOCK, E. H. BARBOUR, C. B. SCHULTZ \\ AND A. L. LUGN1
}

\section{INTRODUCTION}

DURING the course of a field conference on the Pleistocene geology of western Nebraska, varved sediments were found in the headwater drainage of White River near Crawford, Nebraska. A reconnaissance of White River Valley revealed them to be present also in the mid-course, near Interior, South Dakota, and at the mouth, near Chamberlain, South Dakota, where the White River joins the Missouri (Fig. 1). These isolated occurrences of

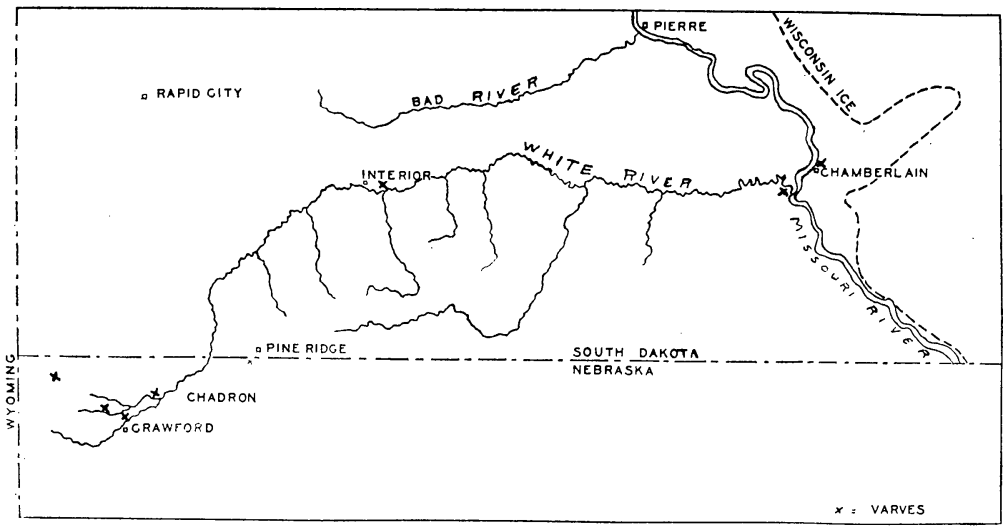

FIg. 1. Index map of White River.

varves, over a distance of 240 miles, are so similar that a correlation seemed possible. Furthermore, since the varves occur within the area where Yuma artifacts are found, it was thought that there was a possibility that they might be of assistance in dating the artifacts.

1 P. MacClintock, of Princeton University, financed by a grant from the Carnegie Institution of Washington; E. H. Barbour, of the Nebraska State Museum; C. B. Schultz, of the Nebraska State Museum; A. L. Lugn, of the Department of Geology, University of Nebraska, and the Nebraska State Geological Survey. 


\section{Description}

Everson's Site. The valley of Sand Creek north of Crawford in Dawes County contains varved lake sediments which were found in two places during the present reconnaissance. The westernmost locality is in the center of Section 36, T. 33 N., R. 53 W., Dawes County, one mile east of Everson's ranch house (Fig. 2). Here Sand Creek and its tributaries have partly dissected the gravelcapped surface of the Chadron clays into badland topography, in the lowland valleys of which varved, slackwater

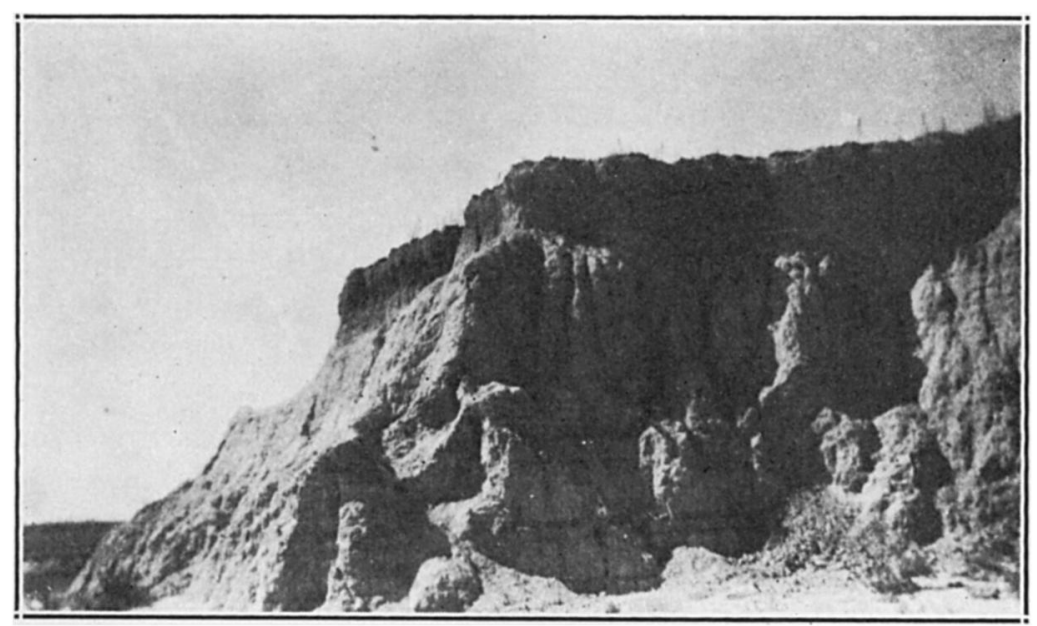

Fig. 2. Varves one mile east of Everson's house.

and alluvial deposits have accumulated. However, the evidence is clear from the presence both of buried soils and of trenches through the deposits, later filled by younger materials, that there has been quite a succession of events during the accumulation of valley fills. One of the episodes was that of a lake in which the varved sediments were deposited. The relation of the deposits is shown in Fig. 3. The sequence of events seems to have been as follows: The gravel-capped surface of the Chadron clay was eroded and gravel let down into the valley so formed, making a veneer on the valley walls, as well as patches in its bottom. Then followed an episode dur- 


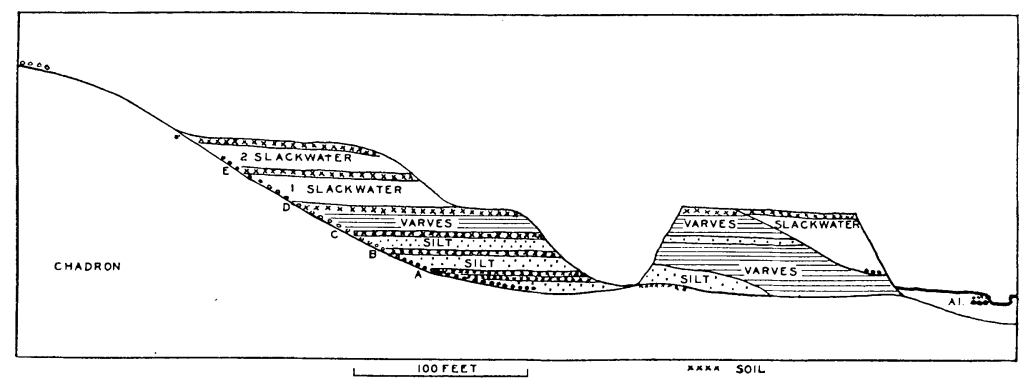

FIG. 3. Diagrammatic cross-section of Sand Creek one mile east of Everson's house.

ing which structureless silt (loess ?) was deposited to several feet in thickness. This was exposed to weathering for a long enough time to form a few inches of black soil, over which was deposited 6 to 8 inches of silt, and it, in turn, weathered to a soil. In Fig. 3, this twin soil zone is specified as Soil A. More will be said about this twin soil later. Then followed the deposition of more structureless silt (loess ?) and the formation of Soil B, about $1 \frac{1}{2}$ feet thick. Again silt was deposited and then weathered to Soil C, which is 2 to 3 feet thick. Erosion then trenched the silt and soil succession at least to the depth of the present valley, cutting it into small buttes and sharp valleys, much like those of the topography of to-day. After this followed the deposition of the varved sediments. It is obvious from their horizontal parallel bedding that they are lacustrine in origin. They are composed of alternating thicker layers of silt and thinner layers of very dark gray, greasy, smooth, fatty, colloidal clay. A two-foot structureless silt layer separates a lower series of varves from an upper series. Then followed an episode of weathering to produce Soil D on the varved sediments, and for a third time, erosion trenched all the deposits to the depth of the present valley. An episode of slackwater deposition ensued, filling up the depressions in the varved sediments and overlapping them against the valley walls. This deposit consists of finely stratified and laminated silts and fine sands so uni- 
formly bedded as to suggest that quiet water conditions must have existed at the time. These first slackwater beds were then weathered to Soil E. A second series of slackwater beds were then laid down, which were weathered to Soil F. And finally, erosion dissected the whole series to the present topography with recent alluvium occupying the valley bottoms.

This somewhat complicated story may be summarized as a sequence of events or episodes as follows:

(1) Formation of gravel-capped surface.

(2) Valley cut and gravel let down as a veneer.

(3) Deposition of the silt (loess 9 ) sequence with interruptions long enough to weather the Soils A and B.

(4) Weathering of the silt to Soil C, and erosion.

(5) Deposition of the varved sediments.

(6) Weathering (Soil D) and erosion of the varves.

(7) Deposition of the first slackwater beds.

(8) Weathering to Soil E.

(9) Deposition of the second slackwater beds.

(10) Weathering to Soil F.

(11) Erosion to present topography.

(12) Deposition of lowland alluvium.

(13) Slight trenching of alluvium.

The measurements of the varves are plotted in Fig. 7. Many invertebrates and vertebrate fossils are found in the soil layers.

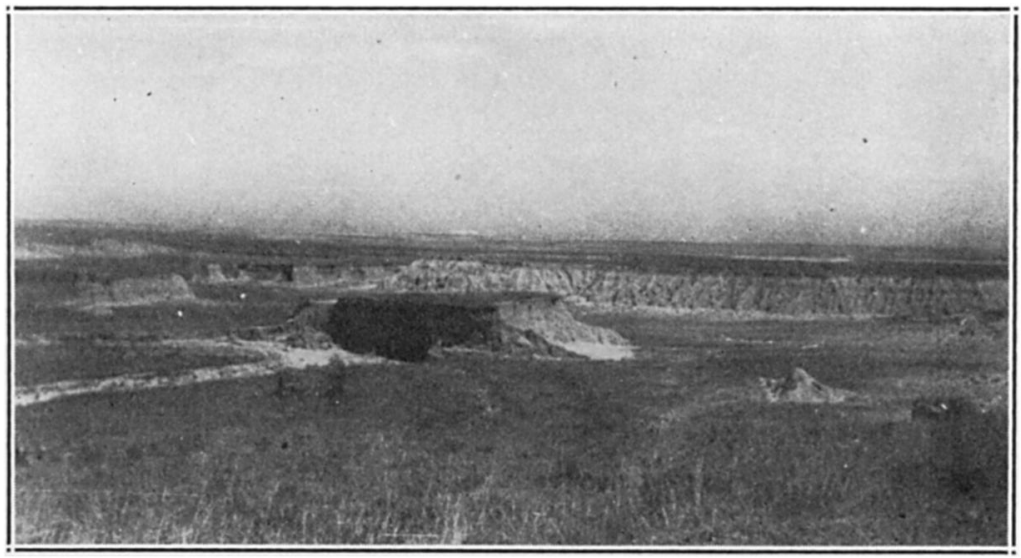

Fig. 4. Sand Creek Valley east from Highway No. 2 bridge. 
Sand Creek Bridge. Varved sediments are seen against the south valley wall and compose part of a small isolated butte in the valley to the east of the highway bridge (Route No. 2 from Crawford to Remington and Orella) across Sand Creek (Figs. 4 and 5). Here, again,

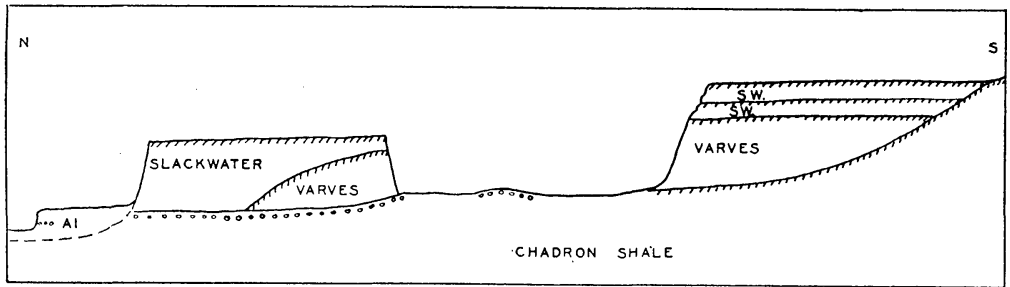

100 FEET

FIG. 5. Diagrammatic cross-section of Sand Creek Valley east of Highway No. 2 bridge. Shading represents soil.

the sequence of events was erosion, deposition, erosion, and deposition, with the varved sediments being one member of the series. The section along the south valley side is as follows:

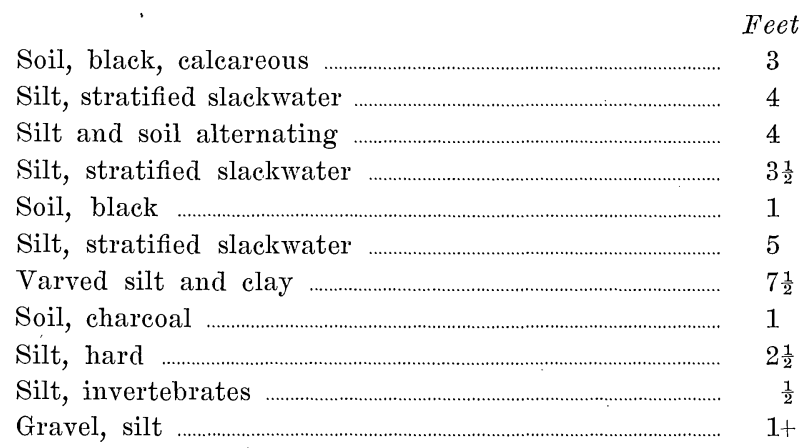

The altitude of the top of the varved sediments was measured as 3,665 AT., which is probably correct to within 10 feet, for the reading was the same on the Paulin altimeter on two different days. The measurements of the varves are shown on Fig. 7.

Big Cottonwood Creek. On the north side of Big Cottonwood Creek, two miles northeast of Whitney and a quarter of a mile above the railroad bridge (SW. 1/4, NW. 1/4, Section 28, T. 33 N., R. 50 W., Dawes County), the 
high, vertical, undercut bank shows 10 feet of varved sediments lying on Pierre shale and overlain by 10 to 15 feet of slackwater silt. While some of the winter layers are good clean-cut ones, many of them are mottled and turbulent in detail, as though they were originally poorly formed or have been materially disturbed since deposition. The latter seems to be more probable. No measurements of the varves were made at this location, since the bank was almost inaccessible at the time of the visit and it would have taken several days of digging to get reliable measurements if such were present. However, from what was seen of the varves, they seem to be typical of the varvd sediments seen elsewhere in the White River drainage. The top of the varves was measured by aneroid as 3,350 feet above sea level.

Pineridge, South Dakota. Two miles west of Pineridge, South Dakota, in a road cut on the side of a small tributary to the White River, eight feet of silt lies on $3 \frac{1}{2}$ feet of varved sediments with a pebble band at their base lying on black soil on silt. Although the varves are well formed, there are only eight winter layers, so no measurement was made.

Interior, South Dakota. Nine miles east of Interior, South Dakota, on the road to Weta, and 100 feet south of the highway bridge across the small stream, eight feet of varved sediments below ten feet of slackwater sands and silts are seen on the east side of the small stream. The elevation of the Chicag'o, Milwaukee and St. Paul Railroad at Interior is 2,381 feet above sea level. The top of the varves, therefore, is very close to 2,340 feet above sea level. The base of the varved sediments is not exposed. There is a soil zone and erosional unconformity between the varved sediments and the overlying slackwater ones. From the fact that the stratification of the slackwater deposits, where they lie against the eroded surface of the varves and gravel, is perfectly horizontal (Fig. 6a), it would appear as though they had been deposited in standing or exceedingly quiet water. Measurements of the varves were made and appear in Fig. 7. 


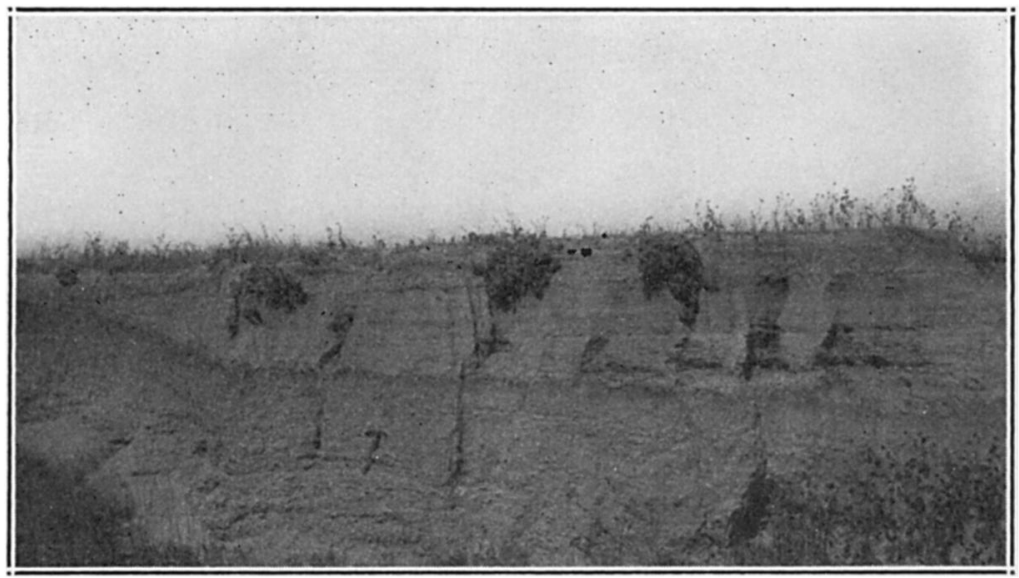

FIG. 6a. Slackwater beds on soil-covered gravel nine miles east of Interior.

Chamberlain, South Dakota. The highway cut one mile north of Chamberlain, South Dakota, in the Missouri valley, ten miles north of the mouth of White River, exposes a section of a terrace in which five feet of varved sediments lie on six feet of gravel and below five feet of stratified sand (Fig. 6b). The elevation of the top of the

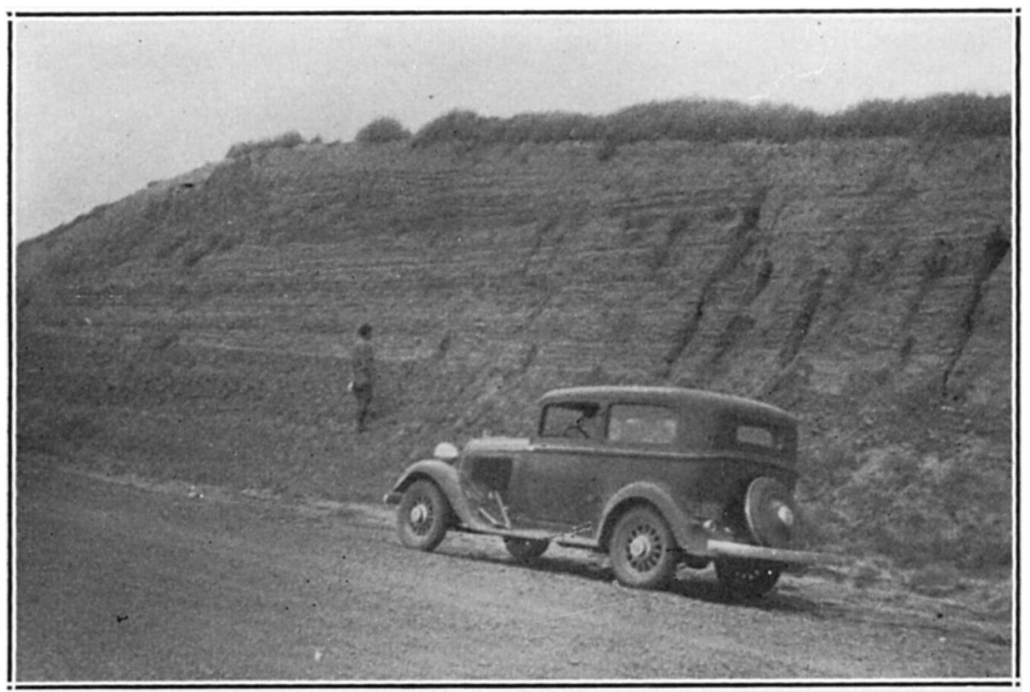

Fia. 6b. Varves one mile north of Chamberlain. 
terrace is about 1,470 feet above sea level. The summer layers of the varves contain some sand, and in three cases, layers one quarter to one half an inch thick of very fine gravel. The winter layers, however, are composed of the typical dark gray, greasy, fatty clay. Measurements of the varves were made and appear in Fig. 7.

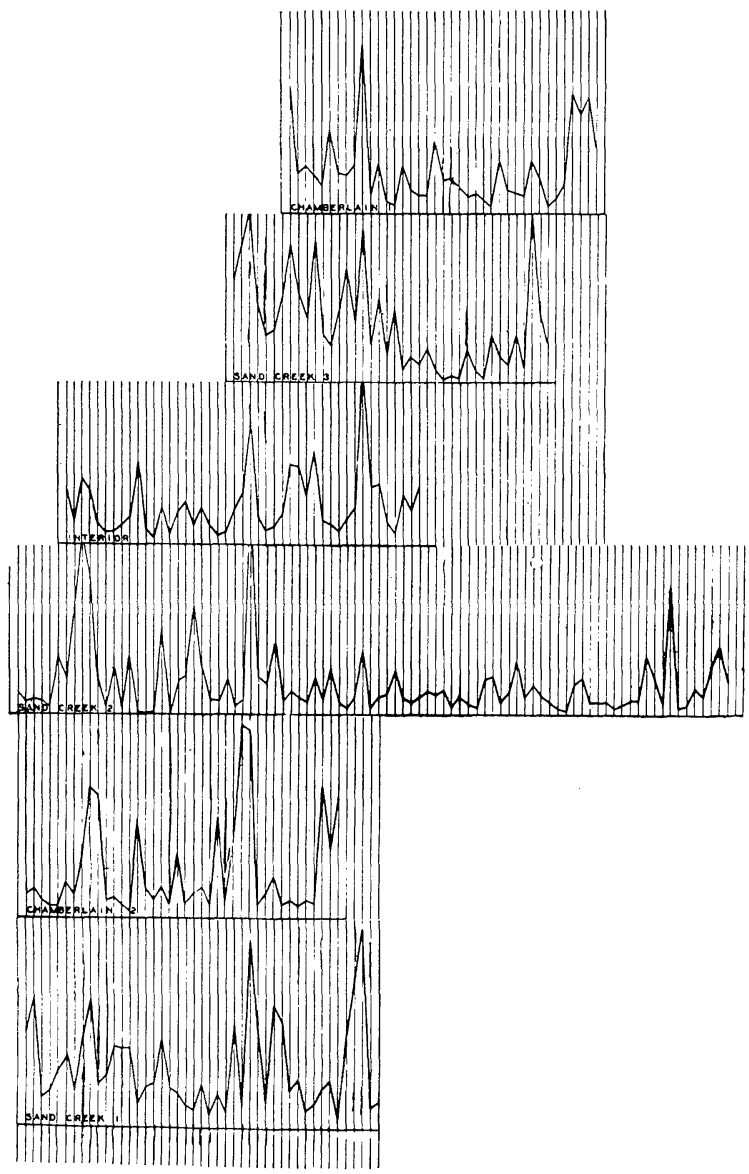

Fig. 7. Graph of the varves in White River Valley. Scale $\times \frac{1}{8}$. Sand Creek $1=$ East side butte east of Sand Creek bridge. Sand Creek 2= One mile east of Everson's house.

Sand Creek $3=$ South bank, east of Sand Creek bridge. Chamberlain $1=$ One mile north of Chamberlain. Chamberlain $2=250$ feet north of Chamberlain 1 . Interior $=$ Nine miles east of Interior. 
Another exposure, 250 feet to the north on the same side of the road and in the same terrace, shows a similar thickness of varves. In this place, however, the base of the varved deposit is not exposed. These varves were measured also and appear in Fig. 7.

Mouth of White River. A terrace on Pierre shale rises to 175 feet above the flood plain of the White River, two miles above its junction with the Missouri. This terrace (1,500 feet altitude) is capped by six feet of medium coarse erratic gravel, over which are $9 \frac{1}{2}$ feet of varved sediments under ten feet of slackwater silts. Only seven varves are present, for the summer layers are exceptionally thick. The summer layers contain some sand and even fine gravel. The winter layers, however, are very good in most cases, being composed of the typical greasy clay. Although the varves were measured, there were so few of them and they were so exceptionally thick that for correlation purposes they seem to have little value and have not been plotted.

\section{Character of the Varves}

There are three main types of varves: those in which there is a gradual transition from coarse material at the bottom to fine at the top, known as diatactic: ${ }^{2}$ those with both coarse and fine material throughout the varve, known as symminct; and those in which there is "no apparent upward decrease in coarseness but the winter layer shows sharp lower as well as upper limitation.", As far as the study of the varves of the White River Valley has gone, only the third type has been noted, in which both the upper and lower limits of the winter layers are sharply demarked. The summer layers are predominantly composed of fine buff silt, but there are occasional thin layers of very fine sand. The winter layers are composed of dark-colored, greasy, smooth, fatty clay, that reveals no grit even between the teeth. There are two

2 M. Sauramo, Comm. Geol. de Finlande, No. 60, p. 78, 1923.

3 E. Antevs, Geol. Surv. Canada, Dept. Mines, Mem. 146, p. 13, 1925. 
types of exceptional winter layers. One type is multiple, having a thin parting of silt, or in several cases, two thin parting's to make a "twin" or a "triplet" winter layer. These parting's are so very thin, $1 / 32$ or $1 / 16$ inch, that they seem to represent a thaw during the winter rather than the whole summer layer of another varve. The second exceptional type of winter layer consists of fatty clay with small masses of silt in turbulent arrangement scattered through it so as to give the layer a mottled appearance. Such winter layers seem to have been produced by a disturbance in some way, either during or after deposition.

The large variations in the thicknesses of the varves, as seen in Fig. 7, show that they were formed under somewhat different conditions from those in Sweden, New England or eastern Canada. This would be expected, since in the latter cases the dominant source of sediment was the glacier, and transportation was characteristically away from the ice-front, through the lake, to an outlet somewhere on the far side. On the other hand, the lake in White River Valley was long and narrow, with the dam at its lower or eastern end. As a result, it is believed that probably some, if not much, of the sediment making up the varves was contributed to the lake by wash within its own drainage basin.

\section{Correlation of the Varves}

The varves, as measured in the field, have been plotted to scale in Fig. 7. No adjustments have been made. There is a chance in measuring the varves for error in judgment in considering a twinned winter layer as part of one rather than two varves. Antevs, in his study of the varve chronology in eastern North America, had so many sections that he was able to adjust those that showed some discrepancies and to discard as abnormal those sections that fit very badly. It may be possible to do the same thing here when more exposures have been measured in the White River basin. 
Keeping these various considerations in mind, there still seems to be more than coincidence in the correlation between the graphs. There are many striking similarities, even while there are obvious discrepancies at many points. On the basis of these graphs, it would appear that the varves are contemporaneous; but whether or not the curves establish contemporaneity, the deduction remains that the varved sediments were deposited in a lake and that in all probability this lake was formed by an ice dam at the lower end of White River, where Wisconsin drift reaches the Missouri valley.

Old Red Lake. Todd ${ }^{4,5}$ described the glaciation of the region near the mouth of the White River, and he found that in pre-Wisconsin time the White River flowed eastward to the site of the present James River. The Wisconsin ice advanced westward and dammed the lower part of this old White River to form a lake, to which he gave the name of Old Red Lake. Its outlet was around the ice edge and across the divide west of the Bijou Hills. Todd did not specify the altitude of the surface of the lake, but at the time he considered that the boulders west of the Missouri, up to 1,800 feet elevation, were ice-rafted to their present situation on the surface of the lake. $\mathrm{He}$ says that "the outlet of Old Red Lake through the Bijou Hills and around the ice at Pratt Creek probably soon cut down to the 350 -foot terrace level (1,685 feet altitude) by the deepening of the channel west of the Bijous." ${ }_{6}$ His maps (Plate XV (1899) and Fig. 3 (1902)) show the lake as a small one extending only a few miles up the White River Valley. In a later paper ${ }^{7}$ he does not mention the lake and attributes the outlying boulders to an earlier glaciation. The present Missouri River is believed to date from Wisconsin time.

The history of the glaciation of the region around Chamberlain seems to need further study and accurate

4 J. E. Todd, Bull. 158, U. S. Geol. Surv., pp. 32-53, and Plate XV, 1899.

5 J. E. Todd, Bull. Geol. Soc. Amer., 13: 27-40, 1902.

6 J. E. Todd, op. cit., p. 53, 1899.

7 J. E. Todd, ScIEnce, n. s. 39: 263, 1914. 
mapping, for till was found on the upland at several places on the west side of the Missouri valley. Such detailed study would reveal whether or not this outlying till was deposited by an extension of the Wisconsin ice sheet or by an older ice sheet, such as the Iowan, Illinoian or Kansan. If the latter were the case, the boulders scattered west of the Missouri might prove to be remnants of a much eroded till sheet instead of ice-rafted material of late Wisconsin ag'e. But with the exception of some details, Todd seems to have correctly expounded the evidence for an ice-dammed lake. The current investigation, however, suggests that this lake extended up the valley of the White River to the neighborhood of Crawford, Nebraska. Leverett ${ }^{8}$ described a moraine of the Dakota lobe lying a little beyond the Altimont Moraine and known as the Bemis Moraine. It was the ice at this stand which dammed the lake at the climax of the last or Mankato ${ }^{9}$ advance of the Wisconsin glaciation.

\section{Origin of the Varved Sediments}

Three possibilities for the origin of the varves might be considered for completeness of the discussion :

(1) The varves may conceivably have been deposited in local lakes in the valley of White River. Such lakes might have been formed as ox-bows or bayous during the normal history of the river or formed by landslides or eolian action during a special episode of the river's history. The presence of the varves in the small tributary valleys near the headwaters of the river renders its applicability very doubtful in regard to the former. And as to the latter, the shape of the valley, particularly at its lower end, seems to preclude landsliding, and a barrier of sand dunes would be partly left in the valley. Furthermore, it is doubtful that varves would accumulate in a lake or lakes thus formed unless the climate was a glacial one, in which case suggestion (3) would be more feasible.

8 Frank Leverett, U. S. Geol. Surv., Prof. Paper 161, p. 67, 1932.

9 F. T. Thwaites, "Outline of Glacial Geology," p. 78, 1934. 
(2) The varves may have accumulated in a lake formed by diastrophism of the region through which the valley passes. There is some evidence of movement along older structural lines in the eastern part of the White River basin. The eastern third of the valley is narrower also, and more deeply trenched than it is in the middle and upper course. But the presence of varves in the Missouri valley at Chamberlain would make necessary the diastrophic barrier across the Missouri in the vicinity of the drift border. The diastrophic hypothesis lacks the support of convincing evidence at the present state of knowledge. It is, also, not known that varves would form in such a non-glacial lake.

(3) The varves may have been deposited in Old Red Lake, which according to Todd was formed by the ice of the late Wisconsin glacier damming the White River.

This third hypothesis seems to be supported by more facts than the others. If it be the correct explanation of the phenomena, the varved sediments are then closely dated in relation to Pleistocene glaciation. They become a good horizon for dating later Pleistocene events in the White River Valley. A relative rise of the western region of more than 2,000 feet since the varves were deposited is indicated, since the varves are now found at 1,500 feet altitude near the mouth of the river, 2,340 feet near Interior and 3,665 feet near Crawford. Physiographic studies have long shown a rise in the western Great Plains, though some have considered the rejuvenation as possibly climatic. We have proof not only of a rise but also of the date and the amount of rise if the hypothesis of a glacial lake be valid.

\section{Human Occupancy}

A great many Yuma points have been picked up in Sand Creek Valley by Nebraska Museum parties ${ }^{10}$ as well as local collectors in the past few years. Artifacts were found in situ in 1935 in the pre-varve soil zones, notably Soil B, Fig. 3. Several typical Yuma artifacts were 10 This material is in the Nebraska State Museum. 


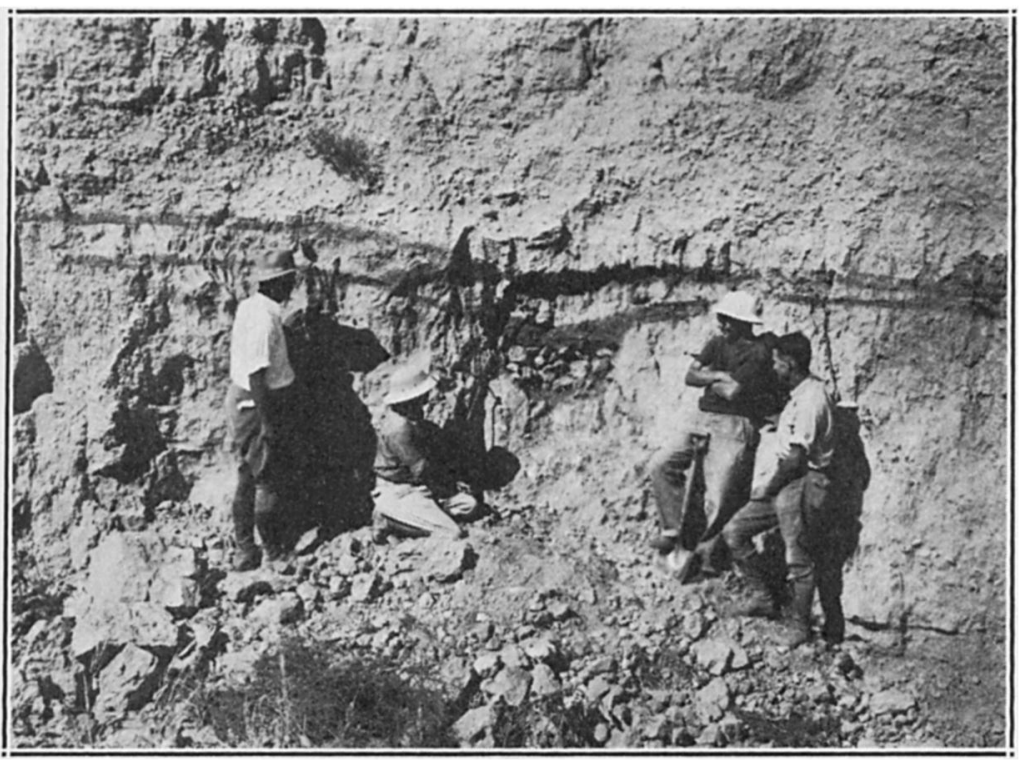

Fia. 8. Fire pit below twin soil zone.

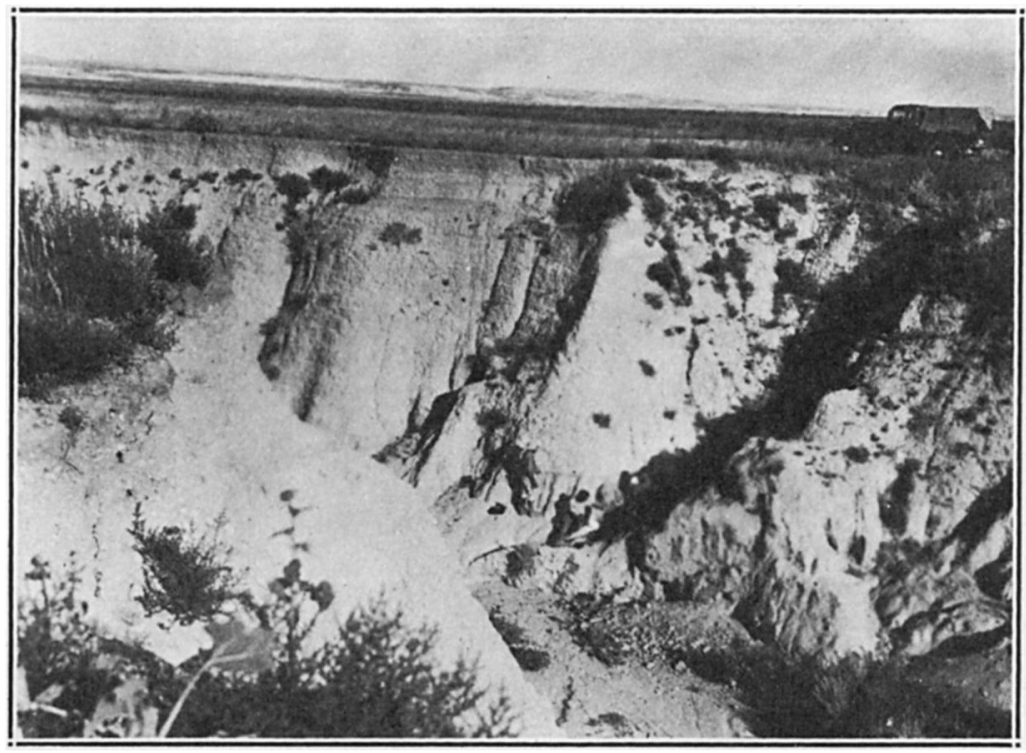

Fig. 9. Deeply buried fire pit. 
found in a nearby locality in a soil zone which seems to correspond to Soil B. Fossil mammal and bird bones were discovered in these same soil zones. In many places, the bones were in a broken and burned condition. Also approximately 150 fire pits were found within the area (Fig. 8). Some of these pits were buried as deeply as 25 feet (Fig. 9). The fire pits, which were filled with much charcoal and burned stones, had been dug to $1 \frac{1}{2}$ to 2 feet below the original habitation surface. Their rims appear to be at the level of the lower member of the twin soil zone A of Fig. 3.

\section{Summary}

There are varve sediments in the White River Valley, as far west as the vicinity of Crawford. It is a possibility that the varved sediments may have been deposited in such an ice-dammed lake, since the White River was dammed at its eastern end by ice of the late Wisconsin glacial invasion. A rise of the western part of the basin, with respect to the eastern part, of 2,000 feet in postWisconsin time, has taken place if this should prove to be the case. Furthermore, the relationships of the soil zones, containing hearth-pits and artifacts, suggest that the latter are older than the varves and hence are of Pleistocene age. More intensive investigation of the sites and the Pleistocene history of the region is planned for the coming seasons.

\section{Acknowledgments}

The writers wish to acknowledge a grant from the Carnegie Institution of Washington for MacClintock's field expenses. They wish to express appreciation to their field assistants: J. S. Templeton, E. L. Blue, Kieth Rathbuin, T. M. Stout, Frank Crabill, David Abbot and Mrs. Marian Schultz. 